\title{
Disengaged Citizens: Involuntarily Returned and Relocated Transmigrants in Southern Kebumen
}

\author{
Laila Kholid Alfirdaus
}

\begin{abstract}
The government's policy to return transmigration program participants, due to the explosion of conflicts in transmigration areas outside Java in the early 2000s to the district where these people originated has raised many questions of citizen engagement. This study aims to identify the impacts of the policy on the returned transmigrants using the idea of citizenship as a framework of analysis. The field research was conducted from December 2012 to February 2013 in Southern Kebumen using in-depth interviews with about 20 informants and direct observations. From the fieldwork, it is found that instead of resolving the problem by returning thousands of transmigration participants, which then was followed with collective relocation, has made the issue more complex. This later aspect caused multiple exclusions to the returned transmigrants socially and politically. The case highlights the government's ignorance of the aspects of geography, ethnicity, cultures, religions, languages, and gender that define citizenship in the Indonesian context, and are impacted by the transmigration policy. Such ignorance has led to the acute political disengagement. Weak inclusion and over-simplification in the handling of the transmigration program (sending, returning, and relocating people from one place to another), due to the single definition of citizen and citizenship, which the government uses in treating people merely as 'materials' for boosting economic growth, instead of as citizens that have rights for recognition, seems to be the core explanation of this case. By elaborating this issue, this paper is expected to enrich the existing study on citizenship, especially the core problems that relate to (forced) transmigration policy, which is rarely discussed among scholars.
\end{abstract}

Keywords: citizenship recognition; civic nationalism; and fragmented citizenship.

\section{Introduction}

This paper discusses the idea of citizenship of the returning transmigrants from outer Java to their original land in Kebumen. The policy was exerted to respond to the escalating violent conflict in transmigration areas, such as Aceh, Kalimantan, Sulawesi, and Papua in order to avoid further impacts of the conflict from the so 
called 'new comer' transmigrants. Although the policy was initially intended to minimize the violent conflict impacts, it later created other problems for the returned transmigrants. They got difficulties in earning money and are constrained in accessing their social and political rights in the new relocation area. From its findings, the study identifies that the use of a single standard for citizenship in moving, and then returning and relocating citizens, without carefully and sufficiently assessing its impacts on the people, will create drawbacks. Using case study methods, the research investigates the policy by interviewing returning transmigrants and the neighbouring community members, as well as observing the relocation area. The field work was conducted from December 2012 to February 2013. The number of informants was about 20 consisting of the returning transmigrants, the neighbouring community and local legislature members, the government officer, NGOs, and academicians. The paper is expected to provide lessons on the importance of accounting for the complex social and political structures that construct citizenship, which in the future could minimize the misleading issues in the transmigration policy.

\section{Citizenship Concept and the Policy Context}

By definition, citizenship refers to the recognition of the citizen's rights and responsibilities more than administrative matters (Gaventa, 2002, p. 10) including, but not limited to, legal status, equal suffrage, welfare access, political participation and freedom, cultural expression, knowledge and information access, organization freedom, and economic redistribution (Isin \& Turner, 2002, p. 1-14). All of these concerns play a crucial part in the implementation of the idea of democracy. Recognition on the principles of equality and justice that is beyond the borders of identity, highlighted with the attributes of ethnics, regions, religions, languages, and gender, addresses the practical application of democracy beyond the procedural process. Equal rights and responsibilities are the basic foundation for the basic idea of citizenship recognition. 
Although the idea of citizenship is crucial, the practice is not as easy as it seems, especially in countries like Indonesia. While the idea of citizenship in general imagines the direct relations between the state and citizen, in Indonesia there are many layers that play equally significant roles in defining citizenship other than state, namely ethnics, region, religion, and so forth. In this case, efforts to manifest the idea of citizenship clearly face a great challenge. The complexity still does not mention the layers within the state body that consist of the national and local government, which is sometimes also contradictory between one another in defining citizenship and who is called as citizen. This multilayer definition creates another complex issue in terms of citizenship recognition.

In this regard, the case of the returned transmigrants, which then followed with the collective relocation in the Kebumen district, Central Java Province, Indonesia has given us a clear picture of how complex it is to handle what we call as citizenship in Indonesia. Each layer of identity, as mentioned earlier, defines its respective idea of citizenship, while overlapping one another, as well as contradicting, so that the identification of "who should do what" is getting blurred. Any policy related to population management (demography) as transmigration and relocation ideally should not ignore any existing definitions of citizenship, posed by ethnic, religious, cultural, regional, and language groups. Unfortunately, when thousands of New Order-promoted transmigration program participants returned from their transmigration areas to Kebumen due to the conflicts in Sampit, Aceh and Poso, in the early stages of reformasi era (1999-2002), the national government did not quickly respond.

Responding to this, Rustriningsih, as Kebumen district-head at the time, took initiatives to handle the problems; something which is actually not her responsibility, but the national government's. She took actions by providing semi-permanent shelters on the state's ground in the southern coastal area of Kebumen in Tanggulangin village, Klirong sub-district. The new relocation area was equipped 
with public toilets and a praying house. She also distributed particular amounts of money and monthly staple foods for several months, several goats per family to raise up their status, 5 fishing ships, coastal agriculture training, and home industry training for female returned transmigrants.

Without disregarding the contribution the local government had made, in fact this policy has been a blunder for the local government. Instead of solving the problem, the policy leaves some other critical problems unsolved, as in terms of land-ownership status and employment. The positive impact shortly ended, and thus failed to give maximum benefits to the returned transmigrants as the policy beneficiaries. It only advantages the national government for the taking over of their responsibility by another party, e.g. Kebumen local government, as well as Rustriningsih and her party, namely Partai Demokrasi Indonesia Perjuangan (PDIP), for the rise of the political popularity after the distribution of the government-funded social assistance to the returned transmigrants.

In fact, after more than a decade since the relocation, the returned transmigrants, who are getting older, continue finding difficulty to earn money, face the uncertainty of the land status, and remain excluded from community decision making. The change in local political structure after two direct elections (2005 and 2010) does not change the pressure on the local government to remedy these issues as soon as possible.

From the case of the returned transmigrants' relocation in Kebumen as mentioned above, this article tries to highlight the complexity of citizenship recognition that has occurred in Indonesia. This article criticizes the use of a single standard of citizenship by the national government to implement transmigration policy while disregarding the other sources of citizenship definitions as mentioned above including regions, ethnics, religions, and so forth.

First, when exerting transmigration policy, the national government only considered economic growth and population distribution. The government did not consider that both the 
transmigration participants and the local residents of transmigration destination areas have their respective binding ties that define and scope their citizenship, called as "communitarian citizenship" (Etzioni, 2011). This includes regions, ethnics, religions, and languages. The failure to engage citizens from these different scopes creates what is called "fragmented citizenship" (Wiener, 1997).

As the transmigration policy did not take into account the scoping for taking the citizens for granted as the object of the policy, problems of overlapping and contradicting identities become unavoidable. The idea of "multicultural citizenship" (Kymlicka, 1995) that regards citizen's rights by respecting their identities, as ethnicity, religion, geographical origins, age, and so forth is forgotten. In the case of returning transmigrants, it is clear that they have the same ethnic and religious identity with the neighbouring community. However, their status as outsiders keeps them excluded from social relations in the village. It has been a public secret that local residents use to have hard relationship with the new comer transmigrants. Such a situation seems to fail to anticipate adjustment issues and to get a proper response in the government's policy.

The case of returned transmigrants and its complexities in relocation policy has shown us a clear irony in the Indonesian population policy. How could policy related directly to citizens, as in transmigration and relocation policy, disregard citizenship? There should be an account on the local cultures in order to avoid the creation of multiple "otherness". In this regard, citizen recognition is the key, and citizen engagement is one of the crucial strategies to manifest it. Indeed, promoting citizenship recognition is not an easy task, but it is not an impossible mission.

Given the complex natures of society, the government will always deal with the complexities of decision making, as in transmigration and relocation policy, i. e. to choose between rational or incremental policy makings (Seal, 2003, p. 94), and between topdown or bottom-up models (Sabatier, 1996, p. 22-36). However, promoting social welfare while strengthening citizen's engagement 
in population policy, as the basis of the citizenship recognition as Mettler and Soss (2004) identify (p. 55-73), through for instance policy feedback (p. 64) can be an alternative. From the case of the returning and relocation of transmigration program participants in Southern Kebumen, this article tries to reflect the problem of citizen recognition and citizen engagement in population policy.

\section{The Policy Complexities in the Relocation of Returned Transmigrants in Kebumen}

Kebumen government relocated thousands of transmigrants returning to the district to save their lives in the late 1990s and early 2000s responding to the massive riots in their transmigration areas. There were about 400 families or 2140 people in that case ("400 Keluarga," 2002, October 16; "2.140 Jiwa," 2003, Juni 20). ${ }^{1}$ Some of them transmigrated since the early 1980s, late 1980s and in the mid 1990s. They were distributed in Aceh, West Sumatra, North Sulawesi, Papua, and Moluccas. It is widely known that most of these areas experienced mass riots during the political transition era. Consequently, the provincial and district governments in the transmigration destination forced transmigrants to quit the areas and return to their original districts.

In the original district, as Kebumen, the sudden coming of returned transmigrants had forced the Kebumen government to respond, although it is clear that this is the responsibility of the national government. Instead of resolving the problems, further problems arose because the response of the Kebumen government was not well-planned, not well-prepared and not comprehensively assessed. The local government, even, was not aware of the scope of the coverage of their authority and responsibility. ${ }^{2}$

Suara Merdeka, "400 Keluarga Eksodan Bisa Picu Kerawanan" (400 Families of "Eksodan" Can Trigger Social Vulnerability), 16 October 2002 and, "2.140 Jiwa Eksodan akan Menjadi Beban" (2140 "Eksodan" People will be the Burden), 20 June 2003.

2 Suara Merdeka, "400 Keluarga Eksodan Bisa Picu Kerawanan" (400 Families of "Eksodan" Can Trigger Social Vulnerability), 16 October 2002 and, "2.140 Jiwa Eksodan 
In addition to providing new residential facilities in the relocation area on the state-owned ground, the Kebumen government also distributed some material assistance, which was supposed to help the returned transmigrants to survive and create new sources of livelihood.

At a glance, the policy sounds very good. However, to what extent it impacted on the whole problem, the resolutions for the returned transmigrants are never clear. Of course, the material assistance is useful. However, the impact only lasted in the shortrun. Instead of securing the returning transmigrants, it later resulted in an even harder situation. Very low income, bad infrastructure, limited public facilities, uncertain land ownership status, exclusion from village decision making process, and the distancing relations with the local residents in Tanggulangin, are amongst the difficulties the returned transmigrants have to face after about a decade since being relocated.

In terms of social and political exclusions, the local government that was taking over the handling responsibility of the returned transmigrants, seems not to be aware that what the returned transmigrants needed were not merely economic materials, but also assistance to integrate and socialize with the local Tanggulangin village residents. They also need the space to involve the community in decision-making, as well as the adjustment with the new coastal environment, which has extremely different circumstances compared with the hilly and mountainous environment they usually lived in. In fact, none of the government's aid is about to touch these nonmaterial necessities. It is not a surprise should problems like social tension and political exclusion becomes a crucial question in those matters later.

The situation worsened with the absence of the national government, as the main responsible party in this case, in dealing with the issue of returned transmigrants' relocation. Meanwhile, it 
is clear that transmigration policy is of the national government's policies. It is ironic that merely because the local government wears the same uniform with the national government then they have to be responsible for what they are not doing, only because the object of the policy is originally from those of local regions, which then are returning back to those regions.

Transmigration policy is clearly outside the Kebumen government's authority at that time (early stage of reformasi era). It is the central government's responsibility. Moreover, because most of the returned transmigrants are already registered as the residents of the transmigration destination areas, as shown in their national ID (KTP), the role of the national government is urgently required. Burdening this financially and politically to the Kebumen government is unfair. The involvement of the Kebumen government should be only in the capacity of supporting the implementation of the national government's policy.

From this experience, we learn about a clear neglect of the state towards the unanticipated excesses of what they have been doing. Ignoring the problem of local acceptance, even by the local village residents, which were basically having the same roots in Kebumen, let us know that there is chronic illness in the building of citizenship conception on the side of the state. This is not to mention problems of acceptance in the transmigration destination that was segregating people into Javanese transmigrants and non-Javanese natives, which has already become a public secret. The same fault was repeated when the government of the transmigration destination returned transmigrants to their original districts due to social and political conflict, such as occurred in the relocation policy in Kebumen.

The way the government exerts its transmigration policy that is not supported with sufficient consideration of social complexities caused by different identities and geographical origins, faced by the participants of the programs as such has led to further critique on the government. As Santoso and Tapiheru (2016) argue, this reflects government's lack of sensitiveness on social and cultural issues. This 
leads to the question of Bhinneka Tunggal Ika (unity in diversity) the government always asserts to promote national integration. The fact that the government does not strive to facilitate social engagement among people from different ethnic identities and geographical origins such as in transmigration policy discussed above leads to the notion that Bhinneka Tunggal Ika is viewed only as a political slogan or jargon.

The existing residents of the local village in Kebumen feel hard to accept returned transmigrants, simply because they are newcomers, attributed as "returned transmigrants", "ekstransmigran", "evacuees", "eksodan", and so forth, although it is clear that they are by ethnic, language, origin, and religion are the same. Consequently, the conception of citizenship of the returned transmigrants experiences multiplied weakening, due to multiple changing of identity affiliations, resulting in fragmented citizenship (Wiener, 1997), which was competing with what the state has been setting up. Simplification and generalization are what seem to happen in the implementation of transmigration and returned transmigrants' relocation policies.

Referring to Gutmann (in Taylor, 1994, p. ix-x), Taylor (1994, p. 39) and Gaventa (2002, p. 10), intended discrimination due to identity differences and social classes are similar with unnecessary impartiality and indifference, as both are degrading to citizenship recognition (or democratic citizenship in Gaventa's term). This is the same with treating citizen having different attributes of identity differently (meaning in discriminatory manners) in issues that need equality. Strong identity binding among the existing village residents followed with the differentiation from returned transmigrants that social engagement was difficult to promote between them is what the state failed to identify. As a result, multiple exclusions and displacements are occurring there. ${ }^{3}$ This is among what Gaventa 
(2002, p. 10) and Clapham (in Abrams, Christian, \& Gordon, 2007) mention as the barriers for democratic governance building.

In the case of returned transmigrants in Kebumen, the recognition of citizenship is neglected by the local government, because they only respond to the case with the idea of benevolent policy. This reflects that local government does not understand nor have any idea about the meaning of citizenship and citizen's rights. Meanwhile, the idea of the state benevolence itself is questionable, because every state's action is political. In the case of returned transmigrants in Kebumen, we can clearly see it, for instance, from the PDIP's photograph; the Kebumen district-head's affiliation party, which is attached in each semi-permanent house built for them. Thus, it is clear that the local decision makers saw this as political commodity, because the policy is financed through APBD (local government budget), and not through PDIP's. The people are seen as the target for a political campaign, and the policy is a means for collecting political support, which is funded by the public.

\section{The Policy Implication: Being IDPs in the Land where Returned Transmigrants Originally were Born}

The origin of returned transmigrants to be IDPs (Internally Displaced Persons) started when they had to accept the relocation policy by the local government. By definition, IDPs is related to forced migration within a state. Involuntary movement within a state's territory as such is what Mooney (2005) sees as displacement, and IDPs is used to mention the subjects of the policy. In Kebumen, relocation occurred in 2002-2003 after around 2140 transmigrants (around 410 families) were returned to their original districts from the areas where horizontal conflicts exploded as in Aceh (with the issue of Aceh Liberation Movement), Kalimantan (with the issue of Dayak-Madura conflict in Sampit) and Sulawesi (with the issue of Moslem-Christian conflict in Poso) in the early 2000s. Amongst these, returned transmigrants from Aceh and Sampit (Kalimantan) were dominating. Most of them, who transmigrated since the New 
Order around 1980s and the early 1990s, were already settled in and had a decent life from having sufficient farming areas to cultivate (around 3-5 acre) and producing cattle in their transmigration region.

In fact, horizontal conflicts not only created problems for the conflicts perpetrators and victims, but also those who lived near the conflict location, including those returned transmigrants. Horrible situations posed a worrisome outcome for the returned transmigrants and the district government in transmigration destination areas. Staying means they would bear a risk of conflict excesses, while returning would mean losing the source of life. Given the situations that were not getting better, those transmigrants finally were returned to their original districts. Kebumen and Madura are amongst the districts that received a significant number of the returning transmigrants and migrants (more than a thousand). As most of those returned transmigrants already lost their property in their original district, finding a residence was a clear issue in Kebumen at the time. At first, returned transmigrants were collected in the Office of Working Training (Balai Pelatihan Kerja). After a year, the Kebumen government decided to provide house buildings on the state's ground in the southern coastal area of Kebumen.

Kamini is one of the returned transmigrants, who still stayed at Kampung "Eksodan" when the researcher visited her for an interview in 2012. She is from Gombong sub-district and was a transmigrant in 1982 to Aceh following her husband. Two decades in Aceh was the golden period for Kamini, who used to live in poverty. She and her family cultivated 3 areas of rice field and vegetable plants. In her first two years, the national government fully supported Kamini and her family's life. They were paid for cultivating their own land while gaining monthly food assistance, as rice, salted fishes, and the other daily needs. She planned to retire in the early 2000s because she would be able to divide her land and distribute it for her 5 children.

However, the explosion of Aceh Liberation Movement 
(GAM) conflict in the late 1990s and early 2000s had forced Kamini to return to Java. A letter from an unidentified sender posted to her house saying that GAM will kill her and all her family members, as well as rumours from her neighbours that GAM would kill Javanese men and use their dead body as fertilizer for palm farming (in Indonesian: "laki-laki Jawa akan dijadikan pupuk sawit oleh GAM"), were a clear threat for her. She left all her belongings, including her profession as a cooking helper in the military barracks near her residential area. After a hard evacuation, she and her family finally arrived at Kebumen in 2002. She joined with the other returned transmigrants from Kalimantan, who had been a year living in Kebumen.

Indeed, Kamini and the other returned transmigrants had to bear a consequence of losing their source of livelihood. Living as an evacuee in Kebumen without a clear job and income is hard, moreover, compared to the life they had in transmigration area, where it was relatively easy to earn money. Unfortunately, Kamini, Santi, and the other returned transmigrants in Kebumen did not have many choices. Responding to this, the Kebumen government prepared for them a semi-permanent house for each family in southern coastal area of Kebumen, near Tanggulangin village, which is $30-40 \mathrm{~km}$ from the city centre. Although becoming a solution for the short-run, relocation in Tanggulangin is also a start for the other bigger problems of returned transmigrants in Kebumen.

First, residing separately from the local Tanggulangin village residents led to a difficult social integration. Social jealousy due to the provision of semi-permanent housing, cattle production facilities and fishing ships for the returned transmigrants for free is one of the explanations of the rise of social tensions between the returned transmigrants and Tanggulangin residents.

The government only prepared a place to reside, which is 200 meter away from the sea, but not a mechanism to socialize. The fact that the closest distance of Tanggulangin residents to "Kampung Eksodan" is about $0.5-1 \mathrm{~km}$ did not become the consideration of the 
local government to initiate local interaction and integration. This is outside the government's relocation design.

Although a rather intensified integration finally occurred after about a decade, the broken relationship between the two has not been totally healed. The recognition of returned transmigrants as the returning family is hard to happen, and they remained identical with the outsiders or newcomers. The aggressiveness of returned transmigrants is understood as an inherent nature of newcomers instead of as an impact of social pressure (Mumfingah, 2005). Returned transmigrants, as a result, suffer from the stigma of being left behind, negative, criminal, allowing prostitution, and poor, so that they were placed as "the others" in Tanggulangin and Kebumen environment in general. They become IDPs in the land where they were actually born.

The local village residents saw that the local government was spoiling the returned transmigrants by providing staple foods and fresh money for the first 3 months, as well as home industry and agriculture training, in addition to housing, cattle (3-4 goats per family) and fishing ships. They argued that the government was having blinded eyes seeing the life condition of the Tanggulangin residents, which are not less poor than the returned transmigrants. Apart from the debate about the social policy design, the Tanggulangin village residents' complaints indicate the weak inclusion of the government in handling the relocation issue, not only to returned transmigrants but also to the existing village residents, highlighting us the very weak social sensitivity of the local government, top-down methods of policy, and reactionary nature of the policy.

While social tension and protest from the existing village residents arose, problems on the side of returned transmigrants are also yet to be resolved. Their profession changing from mountain to coastal farmers, and moreover, fishermen, is not an easy deal for them. As a result, agriculture training the followed the coastal farming experiment totally failed. A respondent said, in their transmigration area, farming did not need much water and fertilizer. 
They also did not need to wait for harvesting. The greater amount of water and fertilizer needed to cultivate coastal farming in Kebumen compared with the mountainous one in the transmigration area posed another challenge for them.

Consequently, some of returned transmigrants tried to earn money in the city or just by being a labour for the Tanggulangin farmers. Some of themevenleave theirhousesin "KampungEksodan" empty, ${ }^{4}$ leading to the perception that returned transmigrants are lazy, instant thinkers, and dependent. Such a thought, indeed, worsens the existing stigma addressed to returned transmigrants, as the residents of "kampung eksodan", a naming that is actually problematic, ${ }^{5}$ and negative. ${ }^{6}$ This is not to mention the remaining problem of land-ownership status, which is unclear until more than a decade after the relocation. The prolonged inability of the local government to make a firm decision on land ownership status has made the burden of being IDPs addressed to returned transmigrants could not be easily cleared up.

\section{Multiple Exclusions and Displacements in the Relocation Policy}

The Kebumen government's policy to provide shelter and assistance for survival in the first three months clearly deserves appreciation. At least, the government already showed its good intention to support the citizens' welfare, apart from the criticism that the policy did not successfully solve the problem. However, the fact that later the relocation policy of returned transmigrants becomes problematic and continuously complex needs further

4 Referring to Millar (in Abrams, Christian, \& Gordon, 2007, p. 1-3) exclusion is the deliberately assigned disjuncture of citizen participation in decision making (Brannan, John, \& Stoker, 2006, p. 993).

5 Until 2009, the number of returned transmigrants decreased until about one fourth out of the initial numbers returning in 2002. Currently, there are 100 families, mixed with new comers from the other Kebumen regions.

6 See, for instance, Suara Merdeka published on 16 October 2002 ("Relokasi Eksodan Terancam Mundur"), and 19 January 2005 ("Warga Eksodan Kesulitan Mencari Makan"). 
attention. There is a need to identify the root of the problems to trace the point where the complexity of the policy started from to identify "who should do what" in that matter.

In the case of returned transmigrants relocation, there is a need to look carefully at the politics exerted by both the central government and the local politicians. There is a need to clarify the responsibility, tasks and functions of the central and local government so that the overlapping and unnecessary responsibility shifting could be avoided. Thus, it would be clear who and how to handle the policy, including its unexpected excesses, like the tension and exclusion between returning transmigrants and the neighbouring community.

However, the local government, which was directly facing the crowd, seemed to be unable to avoid the pressure to fulfil the social demand on them. Instead of resolving the problems, the local government's approach did not lessen the complex problems of returned transmigrants. When the locally initiated policy failed, things get worse than before because the identification of who should be responsible for the failed policy becomes terribly difficult.

The absence of the national government not only caused the burdening on the Kebumen government's budget, but also the multiplying blame was addressed to them. Returned transmigrants, for instance, see the government is half-hearted in resolving the problems. As Sarikun (interview, December 10, 2012), an extransmigrant from Ketapang, West Kalimantan, identifies, the government's assistance only works partially, but never touches the real issue of employment. Saino (Interview, December 10, 2012) adds, what the returned transmigrants needed is an area of farming, as they used to do in their transmigration area. Living without land for farming, for Kamini, Santi (Interview, December 5, 2012). Sanusi (Interview December 5, 2012), and Sari (Interview, December 5, 2012), is like being between life and death.

The existing Tanggulangin residents (Interview, December 5,2012 ), conversely see that the returned transmigrants as getting 
better treatment. They thought the government gave the returned transmigrants a piece land for farming. They also thought returned transmigrants were getting more dependent on the local government, in the midst of the poverty problems that still exist in Tanggulangin.

This makes it clear that even the neighbouring residents in Tanggulangin and Pandan Lor do not always understand the complexities returned transmigrants have to face after relocation. For Mustiko Aji (Interview, December 4, 2012), the misunderstanding of the existing Tanggulangin village residents clearly means problem in the local government's policy, referring to reactionary, highly politicized, and simplified methods of policy-making. Mustiko Aji adds, as handling returned transmigrants is not politically attractive, the ruling politicians in Kebumen government that has changed three times, including Rustriningsih, Nashirudin and Buyar Winarso failed to place this as their priority of attention.

Cahyo (Interview, December 19, 2012) confirms returned transmigrants are reliant on the local residents to earn money through becoming the labourers in coconut sugar production. Meanwhile, Sholahuddin (Interview, December 4, 2012) asserts, the government's assistance ended up merely as a project that did not resolve returned transmigrants' problems. Salim Wasdi (Interview, December 5 , 2012) underlines, the policy exerted merely functions as a political machine to gain votes. Mahrur (Interview, December 5, 2012), academics and ex-legislature member in 2004-2009, addresses similar criticism of relocation and social assistance policies as being poor and in need of assessment. Finally, Irma Susanti (Interview, December 4, 2012), sees the political contents of the policy is more striking than the problem-solving orientation.

Trying to defend from the strong criticisms addressed to the local government, Dian, a member of the legislature body in 2009-2014 asserts that what the government has done is more than enough. ${ }^{7}$ Dian (Interview, December 16, 2012) sees the remaining

The term "eksodan" is used not to disregard its problematic meaning and the entailed 
demands of the returned transmigrants, especially towards the house reconstruction and land-ownership status indicate the never-ended dependence of the returned transmigrants on the government's policy. Sri Hardjayanti (Interview, December 24, 2012), an employee in the Office of Labourers, Trasmigration and Social Protection Office (Disnakertransos), asserts the assistance from the local government was for tackling emergency situations. Returned transmigrants now are expected to have an ability to be self-helping, as it is impossible for the Kebumen government to always assist them.

The contradicting arguments between those advocating and criticizing the relocation policy clearly seem to give us a clear portrait that the problem is between returned transmigrants and the Kebumen government. In fact, it is not. The problem, conversely, should mainly include the national government. In that regards, there is clearly a severe simplification through merely contradicting the returned transmigrants and Kebumen government in relocation policy without involving the national government within. Consequently, exclusion and displacement are not only occurring between returned transmigrants and Kebumen government, or returned transmigrants and the existing Tanggulangin residents, but also between returned transmigrants and the national government, and, more importantly, between the Kebumen government and the national government. In this case, the Kebumen government is only part of the parties that should be responsible for the problems, but also a victim of the non-action choice by the national government and the free rider, vote-seeking local politicians.

\section{Lessons Learned on Citizenship Recognition}

Reflecting from the case of the returned transmigrants' relocation such as occurred in Kebumen, it becomes clear that citizenship recognition should be context-sensitive, and when applied in a country like Indonesia, it should not just consider a single 
standard of citizenship understanding, as the Western countries usually apply. Unlike the governments in Western countries, of which the deal in policy making especially that relates to population only involves the state and citizen, while in the Indonesian context, the deal should include layers outside the state that equally play crucial roles in defining citizenship, including ethnicity, geography of origins, languages, religions, and races. Recognizing citizen's rights is not merely about providing social assistance, but more importantly assuring the rights in the political and social life. In that regard, citizen engagement in policy making is the key.

Indeed, as the case has shown us, citizenship recognition is never as simple as we generally think. Citizenship recognition is not the same as the idea of state benevolence, as Lund (2000) asserts. Referring to Lund (2000), "The idea of benevolence is rather closer to charity, which is usually moralistic in its nature, instead of about political action" (p. 32). Meanwhile, with regarding public policy, does anyone believe in the state's morally promoted action? What looks like moral action in state-citizen relation is always political. In citizenship recognition, what needs more underline is citizen engagement, which does not have anything to do with the state's benevolence. In the case of returned transmigrants' relocation, citizen engagement needs to assert to make sure that social assistance distribution is need and context-based.

In the case of Kebumen returned transmigrants, it is clear that the effort to recognize citizen's rights considers merely single dimensions, namely economy, but fails to identify the other issues related to social and political life. Non-discriminatory manners and political inclusion in community decision making are among the returned transmigrants needs to adjust with the social and political environment. The rise of social tension and the exclusion of returned transmigrants in village decision making are a clear implication of the partial consideration of returned transmigrants' citizenship recognition.

In the case, there is also a tendency of the Kebumen government 
to feel enough was done by distributing a set of social assistance to the returned transmigrants. Ironically, the local government even perceives it as the government's generosity. Although handling the returned transmigrants is part of the national government's responsibility, perception of local government that distributing social assistance is their generosity is misleading. In that case, instead of being generous to the returned transmigrants, the Kebumen government is actually generous to the national government and the local politicians. The national government's inaction and the free rider politicians gained benefits from the responsibility taken over by the Kebumen government. Indeed, in practice state benevolence and state welfare is sometime overlapping, as Gilbert (2002, p. 182) asserts, for equally impacting on the government's budget (Malthus, as cited in Morris, 1994). Therefore, the deliberation scheme, which is clearly also about citizen engagement in policy making, as Bramson (2000), William (2001), and Gastil (2000) assert, is necessary to enable the policy transparency.

Finally, and most importantly, the case of returned transmigrants in Kebumen reminds us of the risk of using a single citizenship standard in exerting policy in the multicultural society like Indonesia. The policy makers should have learned from the transmigration policy, widely known to have resulted in social friction between transmigrants, coined as newcomers, and the existing village regions. Not only between Javanese transmigrants and the existing residents, as found in Aceh and Papua's conflicts, social friction could also be found between Makian ethnic group, as the newcomers, and Kao ethnic group, the existing sub-district residents, in North Moluccas.

The weak social integration as a result of the weaknesses in engagement and unequal social distribution approach the government applied in its transmigration policy, indicates the over simplification of what is coined as the "state" and as "citizen". The government assumes what is called as citizens are those who have to obey the state's policy, and thus, citizenship is just about 
the state-citizen relationships. In fact, there are other elements that bind community into the particular citizenship units and scopes, and equally define citizenship as the state does, as ethnics, geography of origins, religion, language, race, and so forth. Not only complementing each other, sometimes they are overlapping and even contradictory, leading to the fragmented citizenship.

Layers of citizenship definitions in the context of Indonesia, as such, remind us that citizenship recognition is not a simple deal. It needs high sensitivity to the social, cultural and political contexts. In the context of decentralization as currently practiced in Indonesia, the application of citizenship recognition also requires the carefulness in determining who should be responsible for what.

Deliberation and continuous policy feedback are among the mechanisms that might be useful to overcome the social complexities the government has to deal with given the overwhelming identities attributed to the citizens. They enable the government to recognize not only the policy beneficiaries but also the related stakeholders directly and indirectly influenced by the policy. Otherwise, instead of resolving problems, actions taken could lead to the further bigger problems in the future, and turn out to be a blunder for the government in the national and local levels.

\section{Conclusion}

The case of returned transmigrants relocation in Kebumen has let us know that transmigration policy is made without sufficient considerations of social complexities in demography issues. It disregards the social nature of Indonesian community that counts on very important cultural and social identities, which play equal role with the state in determining social and political binding, as described in the idea of citizenship. From the returned transmigrants relocation case, we could then know that the weak design of transmigration policy leads to the - unanticipated-policy excesses, as found in the multiple exclusions of returned transmigrants in Kebumen. 
The case reminds us that making clarification of who should do what since the initial period of policy making is crucial. Otherwise, the other party will take benefit from the choice of inaction and of being free riders. In Kebumen's returned transmigrants relocation case, the national government is the party that benefited from the action of responsibility taking over by the Kebumen government. The other party being advantaged is local politicians who use the public funded social assistance as a vehicle to fertilize their political popularity. Returned transmigrants are not much benefited as they remained facing difficulty in gaining their rightful recognition due to the partial solution the Kebumen government addressed to their real problems. Social tension is among the remaining impacts of the incomplete solution of returned transmigrants relocation.

Finally, the case reminds us that using a single standard definition of citizen and citizenship in the Indonesian context will not help much. Citizenship is not simply a state versus citizen relationships, as many other Western countries experience. Society in the countries like Indonesia is also usually bound with so many identity attributes, which at the same time define their respective idea of citizenship as the state does. Therefore, the idea of citizenship becomes multi layered and complicated, which includes geography of origins, status in transmigration policy, location of residential area, region written in National ID, and nationality and locality of returned transmigrants.

Consequently, citizenship recognition is never a simple issue to deal with. Being contextually and culturally sensitive is, therefore, a prerequisite for promoting citizenship recognition. Deliberation and policy feedback mechanism could be among the ways to tackle the social complexities related to transmigration and relocation policy, not only towards the policy beneficiaries, but also towards the other stakeholders directly and indirectly influenced by the policy. 


\section{References}

Abrams, D., Christian, J., \& Gordon, D. (Eds.). (2007). Multidisciplinary Handbook of Social Exclusion Research. Chicester: John Wiley and Son.

Bramson, R. A. (2000). The deliberative public managers: Engaging citizens in productive public conversations, (Doctoral Dissertation). The Union Institute Graduate College, Ann Arbor.

Brannan, T., John, P., \& Stoker, G. (2006). Active citizenship and effective public services and programmes: How can we know what really works?. Urban Studies, 43 (5/6), 993-1008.

Etzioni, A. (2011). Citizenship in a communitarian perspective. Ethnicities, 11 (3), 336-349.

Gastil, J. (2000). Is face-to-face citizen deliberation a luxury or a necessity? Political Communication, 17, 357-61.

Gaventa, J. (2002). Introduction: Exploring citizenship, participation, and accountability. International Development Studies (IDS) Bulletin, $33(2), 1-11$.

Gilbert, N. (2002). Transformation of the Welfare State: The Silent Surrender of Public Responsibility. London: Oxford University Press.

Isin, E. \& Turner, B. (Eds.). (2002). Handbook of Citizenship Studies. London: Sage.

Kabeer, Naila. (2002). Citizenship and the boundaries of the acknowledged community: Identity, affiliation, and exclusion. International Development Studies (IDS) (Working Paper No. 171), 1-48.

Kymllicka, W. (1995). Multicultural Citizenship: A Liberal Theory of Minority Rights (Oxford Political Theory). New York: Oxford University Press.

Lund, B. (2002). Understanding State Welfare: Social Justice or Social Exclusion?. London: Sage.

Mettler, S., \& Soss, J. (2004). The Consequence of Public Policy for Democratic Citizenship: Bridging Policy Studies and Mass Politics. Perspectives on Politics, 2(1), 55-73.

Mooney, E. (2002). The Concept of Internal Displacement and The Case of Internally Displaced Persons as A Category of Concern. Refugee Survey Quarterly, 24(3), 9-26.

Moris, L. (1994). Dangerous Classes: The Underclass and Social Citizenship. New York: Taylor and Francis.

Mumfingah. (2005). Pengaruh Bimbingan Keagamaan Terhadap Penurunan Perilaku Agresi Warga Pemukiman Eksodan Aceh di Desa Tanggulangin Kecamatan Klirong Kabupaten Kebumen (Undergraduate thesis). Fakultas Syari'ah IAIN Walisongo, Semarang.

Sabatier, P. A. (1986). Top-Down and Bottom-Up Approaches to 
Implementation Research: A Critical Analysis and Suggested Synthesis. Journal of Public Policy, 6 (1), 21-48.

Santoso, P., \& Tapiheru, J. (2016). Inevitability of Hybrid Model: Trajectory of The State's Transformation in Post-Suharto Indonesia. In Wilhelm Hofmeister \& Edmund Tayao (eds), Federalism and Decentralization: Perceptions for Political and Institutional Reforms (pp.189-208). Konrad-Adenauer-Stiftung, Singapore in collaboration with Local Government Development Foundation, Makati City.

Seal, W. (2003). Modernity, Modernisation and The Deinstitutionalisation of Incremental Budgeting in Local Government. Financial Accountability and Management, 19 (2), 93-116.

Relokasi Eksodan Terancam Mundur. (2002, October 16). Suara Merdeka. Retrieved from http://www.suaramerdeka.com/harian/0210/16/ dar27.htm on 30 May 2017 at 10.58 am.

400 Keluarga Eksodan Bisa Picu Kerawanan. (2003, March 20). Suara Merdeka. Retrieved from http://www.suaramerdeka.com/ harian/0303/20/dar16.htm on 30 May 2017 at 10. $57 \mathrm{am}$.

2.140 Jiwa Eksodan Bakal Jadi Beban. (2003, June 20). Suara Merdeka. Retrieved from http://www.suaramerdeka.com/harian/0306/20/ dar15.htm on 30 May 2017 at 10. 55 am.

Eksodan Kebumen Dapat Bantuan 11 Kapal. (2003, August 8). Suara Merdeka. Retrieved from http://www.suaramerdeka.com/ harian/0308/08/dar24.htm on 30 May 2017 at 10. 59 am.

Warga Eksodan Kesulitan Mencari Makan. (2005, January 19). Suara Merdeka. Retrieved from http://www.suaramerdeka.com/ harian/0501/19/ked11.htm on 30 May 2017 at $11.00 \mathrm{am.}$

Taylor, C. (1994). Multiculturalism: Examining the Politics of Recognition. Princeton: Princeton University Press.

Wiener, A. (1997). Making Sense of The New Geography of Citizenship: Fragmented Citizenship in The European Union. Theory and Society, 26 (4), 529-560.

Williams, S. (2001). Citizen Engagement Through Public Deliberation. Journal of Family and Consumer Sciences, 93(2), 12-13. 
Appendix 1: Map of Tanggulangin, Klirong, Kebumen

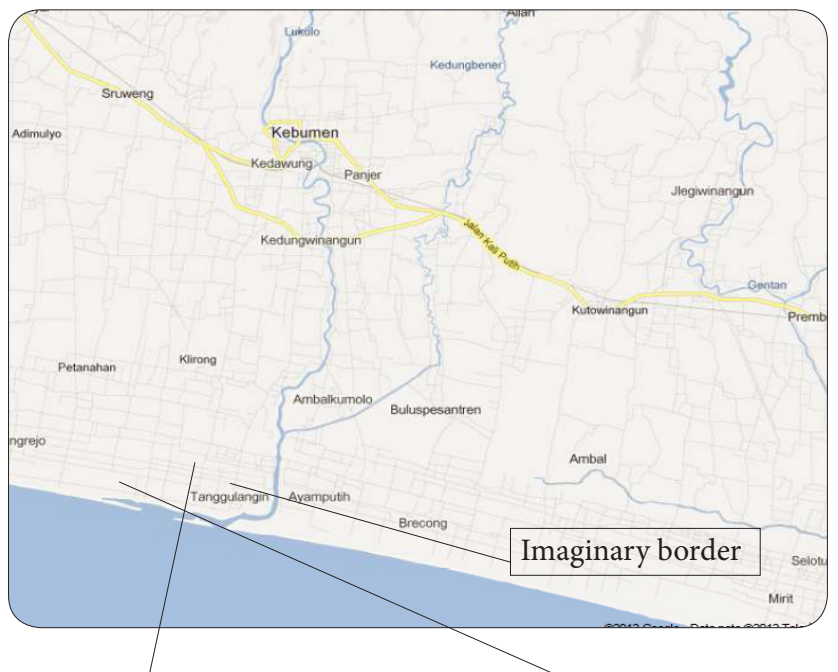

Source: $h t t p: / /$ maps.google.co.id/maps? $h l=i d \& v p s r c=0 \& i e=U T F 8 \& l l=-7.73072$. Retrieved 31 October 2012, at 21.36.

The residential area of the existing Tanggulangin village

The residential area of returned transmigrants

Appendix 2: Photograph of semi-permanent housing of returned ransmigrant

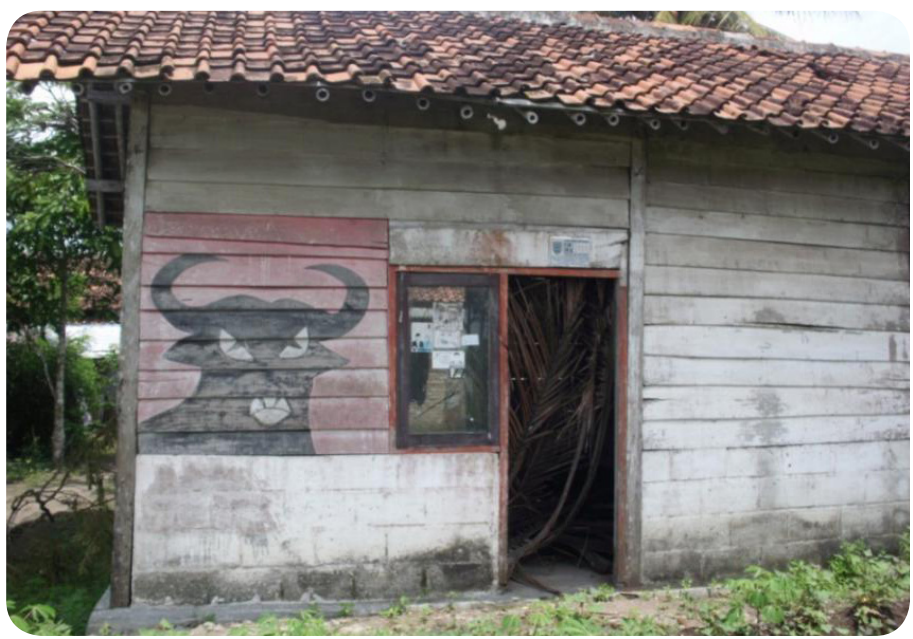

